\title{
Continuous Spectographic Analysis of Vanadous and Vanadic Ions
}

Prepared by

J. V. Bishop, R. A. Dutcher, M. S. Fisher, S. Kotlle, R. A. Stowe

Omni Tech International, Ltd.

Prepared for

U.S. Nuclear Regulatory Commission 


\section{AVAILABILITY NOTICE}

Availability of Reference Materials Cited in NAC Publicatione

Most documents cited in NRC publlcations whll be avallable from one of the followng sources:

1. The NRC Publlc Document Room, 2120 L Street, NW, Lower Level, Washington, DC 20555-0001

2. The Superintendent of Documents, U.S. Government Printing Offlce. Mall Stop SSOP, Washington, DC 20402-9328

3. The National Technical Information Service, Springfieid, VA 22161

Although the llsting that follows represents the majority of documents clted in NAC publications, It is not intended to be exhaustive.

Roferenced documents avallable for inspection and copying for a fee from the NRC Publlc Document Room Include NRC correspondence and Internal NRC memoranda; NRC Offlce of Inspection and Enforcement bulletins, circulars, Information notlces, Inspection and Investloation notices; Llcensee Event Reports; vendor reports and correspondence; Commlssion papers; and applicant and Ncensee documents and correspondence.

The following documents in the NUREG serles are avallable for purchase from the GPO Sabe Program: formal NRC staff and contractor reports, NRC-sponsored conference proceedings, and NRC booklets and brochures. Also avallable are Regulatory Guldes. NRC regulations in the Code of Federal Regulations, and Nuclear Regulatory Commission Issuances.

Documents avallable from the National Technical Information Service include NUREG serles reports and technical reports prepared by other federal agenclee and reports prepared by the Atomtc Energy Commisslon, forerunner agency to the Nuclear Regulatory Commission.

Documents avallable from public and special technical lbrartes mclude all apen Hterature Hems, such as books. journal and periodical articles, and transactions. Federal Reglster notlces, foderal and state legislatlon, and congressional reports can usuall, be obtalned from these librartis.

Documents such 88 theses, dissertations, forelgn reports and translations, and non-MRC conference proceedings are avaliable for purchase from the organization sponsoring the publication clted.

Single coples of NRC draft reports are avallable free, to the extent of supply, upon wrteten request to the Office of Information Resources Management, Distribution Section, U.S. Nuclear Regulatory Commission. Washington, DC 20555-0001.

Coples of Industry codes and standards used in a substantive manner in the NRC regulatory process are maintained at the NRC LIbrary, 7920 Norfolk Avenue, Bethesda, Maryland, and are avallable there for reference use by the public. Codes and standards are usually copyrighted and may be purchased from the originating organization or, If they are Amerlcan National Standards, from the Amerivan National Standards Institute, 1430 Broadway, New York, NY 10018.

\section{DISCLAIMER NOTICE}

This report was prepa:ed as an account of work sponsored by an agency of the United States Government. Neither the United States Government nor any agency thereof, or any of their employees, makes any warranty. expresed or implied, or assumes any legal liability of responsibility for any third party's use, or the results of such use, of any information, apparatus, product or process disclosed in this report, $\alpha$ represents that its use by such third party would not infringe privately owned rights. 
NUREG/CR-6047

$1 \mathrm{R}, 1 \mathrm{~S}$

\section{Continuous Spectrographic Analysis of Vanadous and Vanadic Ions}

Manuscript Completed: May 1993

Date Published: October 1993

Prepared by

J. V. Bishop, R. A. Dutcher, M. S. Fisher, S. Kottle, R. A. Stowe

Omni Tech International, L.td.

Midland, MI 48640

\section{Prepared for}

Division of Regulatory Applications

Office of Nuclear Regulatory Research

U.S. Nuclear Regulatory Commission

Washington, DC 20555-000 i

NRC FIN L2579 


\begin{abstract}
Spectroscopic wethods were investigated for the determination of vanadium ions in aqueous solutions arising in the production of vanadium (II) formate and its use in the LOMI (Low Oxidation-state Metal Ion) process for the chemical decontamination of systems in nuclear power plants.

In the LOMI process, a dilute solution of vanadous formate and picolinic acid is used. The vanadous formate reduces metal oxides in the scale on the equipment, causing the scale to break up and become suspended. The picolinic acid chelates these materials and makes them soluble. During the decontamination the progress is followed by analyses of the metal ions and of the radioactivity. When the values stop increasing, the decontamination is terminated. At present, it cannot be determined if the values are no longer changing due to all the scale being removed or due to the vanadous ion being spent.

Infrared and ultraviolet-visible analysis were investigated as the means of analyzing for vanadium species. It was found that the complex formed by $\mathrm{V}(\mathrm{II})$ with picolinic acid could be used for colorimetric analysis for V(II) in the range of $0-0.011$ moles/liter, which encompasses the concentration range used in the LOMI process. The findings will be used to develop an on-line instrument for continuously monitoring V(II) during decontamination.
\end{abstract}




\section{TABLE OF CONTENTS}

Page

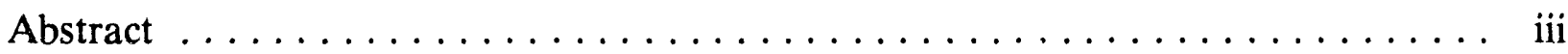

List of Figures $\ldots \ldots \ldots \ldots \ldots \ldots \ldots \ldots \ldots \ldots \ldots \ldots \ldots \ldots \ldots$

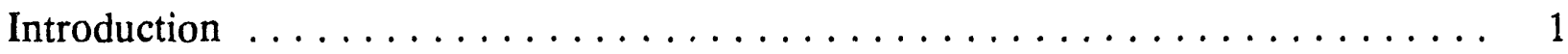

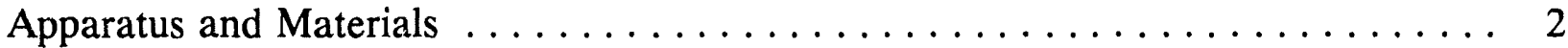

Discussion of Results

I. Reflectance Spectroscopy

A. Infrared Region $\ldots \ldots \ldots \ldots \ldots \ldots \ldots \ldots \ldots \ldots \ldots \ldots \ldots \ldots \ldots \ldots \ldots \ldots$

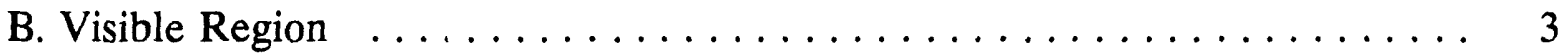

II. Transmission Spectroscopy

A. Monitoring Production of $\mathrm{V}(\mathrm{II})$ from V(IV) $\ldots \ldots \ldots \ldots \ldots$

B. Monitoring V(II) at LOMI Concentration . . . . . . . . . . . 5

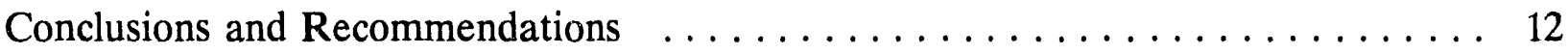

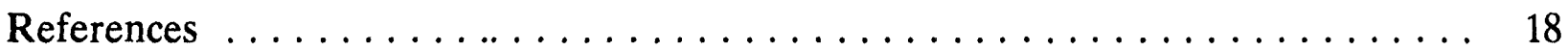




\section{LIST OF FIGURES}

Figure No.

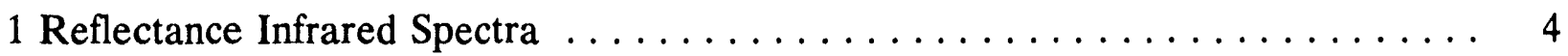

2 Absorbance of $0.2 \mathrm{M}$ Vandanium Formate Solutions $\ldots \ldots \ldots \ldots \ldots \ldots$

3 Vanadous Formate/Picolinic Acid (1:3 Ratio) $\ldots \ldots \ldots \ldots \ldots \ldots \ldots \ldots$

4 Vanadous Formate/Picolinic Acid, Absorbance as a Function of Concentration

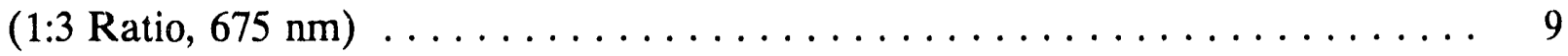

5 Vanadous Formate/Picolinic Acid (1:9 Ratio) $\ldots \ldots \ldots \ldots \ldots \ldots \ldots \ldots$

6 Effect of Picolinic Acid Concentration $\ldots \ldots \ldots \ldots \ldots \ldots \ldots \ldots \ldots \ldots \ldots$

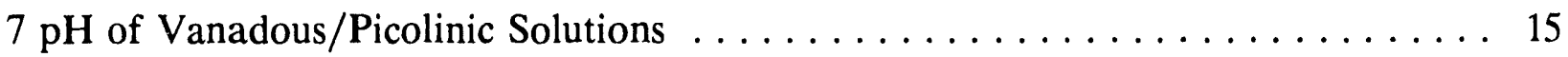

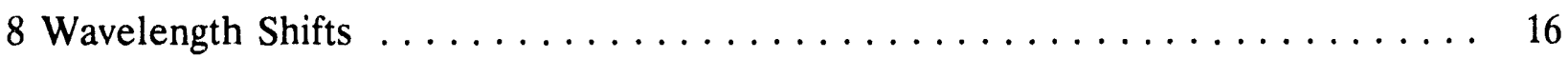

9 Spectra of Interfering Ions $\ldots \ldots \ldots \ldots \ldots \ldots \ldots \ldots \ldots \ldots \ldots \ldots$ 


\section{FOREWORD}

The NRC supports high-quality research proposals from small business firms on important scientific or engineering problems and opportunities that could lead to significant advancement in the safety of nuclear operations. One of the topical areas where proposals are solicited is the area of radiation protection and health effects, including improved decontamination technologies that will reduce personnel dose or decontamination cost or improve decontamination effectiveness. The Continuous Spectroscopic Analysis of Vanadous and Vanadic Ions project was selected because it met these criteria. Under this project two spectroscopic methods were tested for determining the time when the decontamination process is complete or the process solution has been expended. The approach used was to analyze the test solution for the presence of vanadium ions in concentrations that would be normally found in the LOMI decontamination solution to determine when the process was complete.

NUREG/CR-6047 is not a substitute for a regulation and compliance is not required. The approaches and methods described in this NUREG are provided for information only. Publication of this report does not necessarily constitute NRC approval or agreement with the information contained therein.

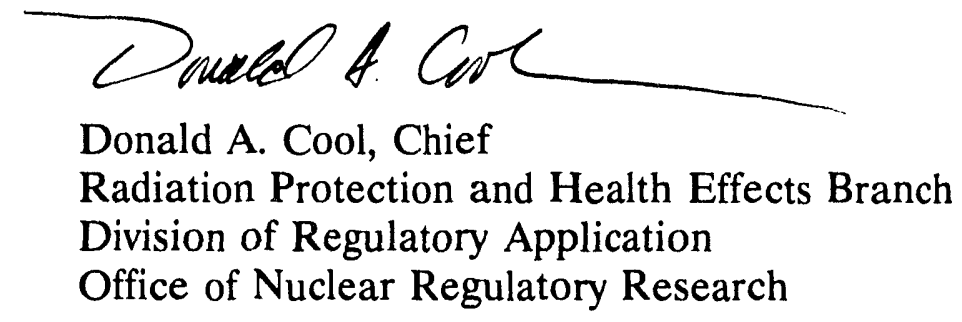




\section{INTRODUCTION}

Vanadium in the +2 oxidation state is a powerful reducing agent which is used with a chelating agent in the Low Qxidation-state Metal Ion (LOMI) method (Ref. 1,2) for removing refractory metal oxide deposits from the interior surfaces of stainless-steel equipment in nuclear power plants. This process is one of several methods which are employed for decontamination in boiling water ruid pressurized water plants. If those deposits are not removed, the radiation field in the vicinity of the piping and associated pumps rises, primarily because of the presence of Co- 60 . That adversely affects permissible safe working times available to plant operating personnel.

In a LOMI cleanup, a dilute mixture of vanadous formate and formic and picolinic acids is circulated in deionized water through the system which is to be cleaned. The reducing agent and chelant, acting in concert, solubilize deposited iron, nickel, cotalt, chromium, etc. At the completion of the cleaning process the dissolved metals are removed and concentrated for disposal by means of an ion exchange bed. During the course of a decontamination it is necessary to monitor radioisotope concentrations and the concentration of metal which is solubilized. When these values no longer increase, the decontamination is terminated. At present it cannot be determined whether these values are no longer changing because scale removal is complete or because of vanadous ion depletion. If the vandous ion is being spent before the scale is completely removed, perhaps the process could be modified to make it more effective. It was the objective of the research described herein to assess the feasibility of performing a spectrometric analysis for V(II) which could be made on-line, continuous, and automatic.

Clark (Ref. 3) reviewed the older gravimetric, volumetric and colorimetric methods for the determination of vanadium. In the titrametric method which was used in the present work V(II) was titrated with aqueous potassium permanganate solution (Ref. 4). Total vanadium was determined by reduction of all vanadium present to V(II) by means of a Jones reductor, followed by permanganate titration (Ref. 5). The analysis is somewhat timeconsuming for concentrations in the range of $0-1 \mathrm{M}$, which is the range of interest in the manufacture of vanadous formate. At concentrations in the vicinity of $0.005 \mathrm{M}$, as used in the LOMI process, it is inadequate. 
The spectra of vanadous and vanadic ions have been investigated. (References 6, 7). Upon the addition of picolinic acid (Pic), dilute V(II) formate solution exhibits an intense purple color, suggesting that colorimetric measurements might be usable for the analysis and that the molar absorbance might be large. Since the concentrations which are present during the manufacture of vanadous formate were expected to be too strongly absorbing to permit direct transmittance determination, it was decided to evaluate a reflection technique as a means of securing a sufficiently short path length. The alternative would be the use of dilution, which would be acceptable for laboratory use, but would severely complicate the design of an on-line analyzer. The cell which was chosen was one used for FMIR (an acronym for frustrated multiple internal reflectance) in which the light beam undergoes multiple reflections at the interface between a suitable prism and the solution being examined (Ref. 8).

\section{APPARATUS AND MATERIALS}

The ultraviolet-visible wavelength spectra were obtained through the use of a Carey Model 118 double-beam spectrophotometer (Carey Instruments, Richmond, CA) with ultraviolet and incandescent light sources and photomultiplier detector. Scans were conducted at $1 \mathrm{~nm} / \mathrm{sec}$ with a chart display of $100 \mathrm{~nm} / \mathrm{inch}$ and a $0-1$ linear absorbance scale.

For work at the smallest concentrations, standard rectangular silica cells with $10 \mathrm{~mm}$ path length were employed; the cells held approximately 3 $\mathrm{ml}$. Where a shorter path length was needed, International Crystal (Garfield, $\mathrm{NJ})$ Type 21 glass cells with a $1 \mathrm{~mm}$ path were employed.

The infrared data were gathered through the use of a Nicolet Instrument Company (Madison, WI) Model DX Fourier-transform (FTIR) instrument. For each sample 20 scans were collected at a resolution of 4 wavenumbers. The infrared scans and some visible wavelength measurements were conducted using an Harrick Scientific Corp (Ossining, NY) Model PLC9 prism liquid cell with a zinc selenide prism.

The V(II) was obtained as a commercial preparation from VF Sales (Midland, MI) as vanadous formate solution, approximately $0.25 \mathrm{M}$, 
containing excess formic acid at approximately $0.23 \mathrm{M}$. All vanadium compound solutions with concentrations greater than 200 millimolar were analyzed by redox titration (Ref. 4).

Picolinic acid (2-pyridinecarboxylic acid (CAS 98-98-6) assaying 98.5\% was obtained from Nepera, Inc., Harriman, NY 10926. The other chemicals used were standard laboratory-grade reagents.

The chemicals were prepared as stock solutions which were stored in a nitrogen-purged glove box in which dilutions were performed and the spectrometer cells were filled. To reduce the possibility of loss of V(II) due to the intrusion of atmospheric oxygen, the V(II) was added immediately before the spectrophotometric observations were performed.

\section{DISCUSSION OF RESULTS}

I. Reflectance Infrared and Visible Spectroscopy

\section{A. Infrared Region}

FMIR spectra were gathered on solutions $0.217 \mathrm{M}$ in V(II), picolinic acid, and the vanadous picolinate complex at $400-4,000$ wavenumbers (Figure 1). The infrared spectra showed absorbance due to water, formic acid and picolinic acid. No features were recognized which could be specifically attributed to interaction between the vanadium and the other components which were present.

\section{B. Visible Region}

Measurements in the visible region were unsuccessfully attempted on the vanadous picolinate complex. There was a strong background absorbance which varied from 0.45 near $300 \mathrm{~nm}$ to 0.3 at $700 \mathrm{~nm}$ which had as its source the yellowish color of the zinc selenide optical element. Any absorbance which may have resulted from the complex was not observed. 
FIGURE 1

REFLECTIVE INFRARED SPECTRA

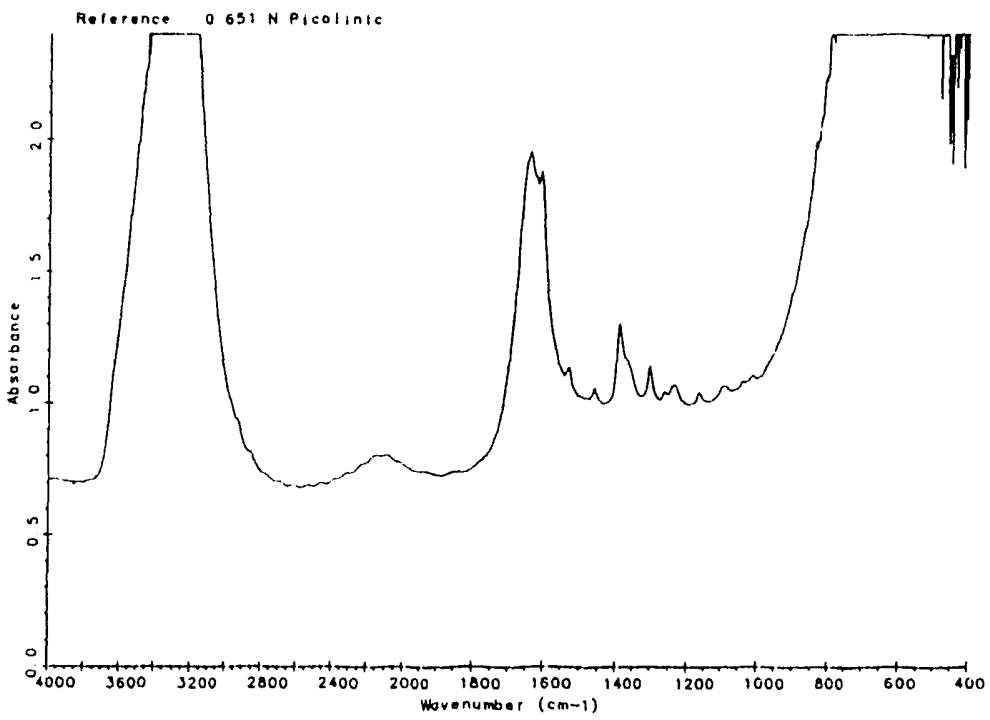

Reference

0.651 N Picolinic Acid

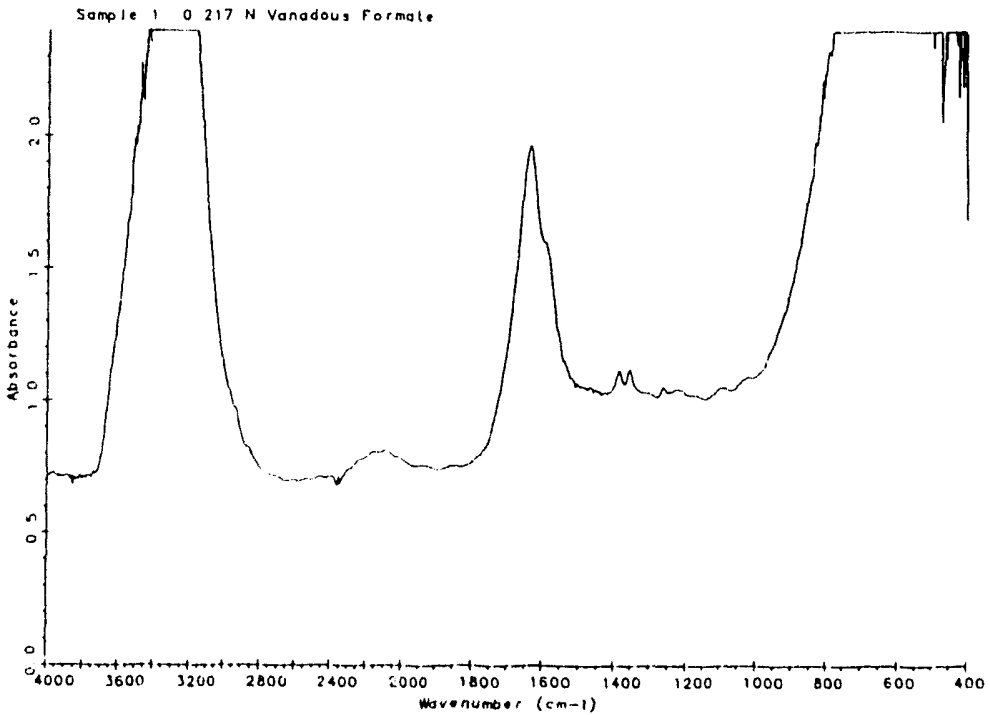

Sample 1

0.217 N Vanadous Formate

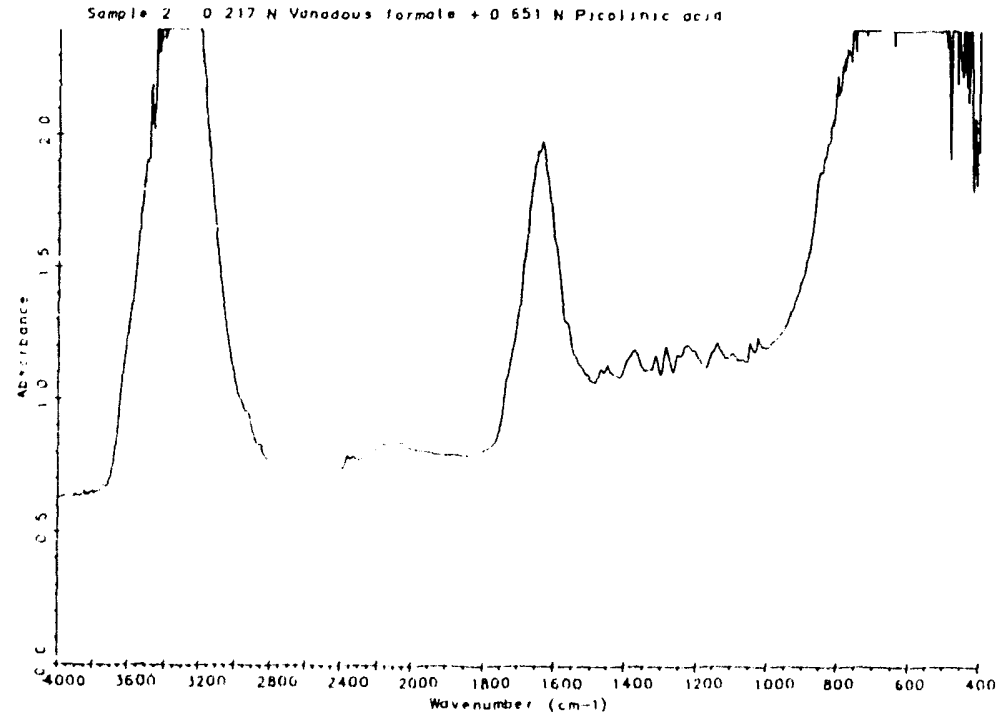

Sample 2

$0.217 \mathrm{~N}$ Vanadous Formate

0.651 N Picolinic Acid 


\section{Transmission Spectroscopy}

\section{A. Monitoring Production of V(II)}

The transmission spectra of vanadium formate solutions in which the metal was in the $+2,+3$, and +4 oxidation states showed dramatic differences. A $0.217 \mathrm{M} \mathrm{V}$ (II) solution was a dark purple with $\lambda_{\max }=565 \mathrm{~nm}$. A $0.22 \mathrm{M}$ $\mathrm{V}$ (III) solution was green, with purple tints, while a $0.22 \mathrm{M} \mathrm{V(IV)} \mathrm{solution}$ was blue. The spectra which were obtained are shown in Figure 2. At approximately $750 \mathrm{~nm}$, a distinct pattern of changes in absorption could be followed for the 3 species. The absorbance is too large for solutions in that concentration range to be usable without dilution. Further investigation of the use of the reflectance technique would be warranted if a suitable prism were selected which might be free from the interference discussed in Section I.B, above.

\section{B. Monitoring V(II) at LOMI Concentration}

The spectra presented in Figure 3 show the absorbance of V(II) in a 1:3 molar ratio with picolinic acid for vanadium concentrations of 0.00111 to $0.0111 \mathrm{moles} /$ iter $(1.11-11.1 \mathrm{mM})$ at $1 \mathrm{~mm}$ path length. The corresponding numerical data are presented in Table 1, while the absorbance is graphed as a function of concentration for a wavelength of $675 \mathrm{~nm}$ in Figure 4. The line drawn through the origin shows the absorbance expected based on the upper data points. The absorbance follows a linear dependence on concentration, in accord with theory, except at low absorbance values.

Figure 5 shows the spectra resulting from a $9 / 1$ molar ratio of picolinic acid to $\mathrm{V}$ (II) at $1 \mathrm{~mm}$ path length. The already complex spectra which were observed at a 3/1 Pic/V(II) ratio (Figure 3) have become broadened toward longer wavelengths.

Changes in absorbance of $0.005 \mathrm{M} \mathrm{V}$ (II) as the picolinic acid ratio was varied are shown in Figure 6. For this vanadium concentration, which is in the LOMI process range, the average absorbance at $565-575 \mathrm{~nm}$ increases with increasing picolinic acid concentration until a $6 / 1$ ratio is reached. The inference is that the complex requires 6 picolinic acid molecules for each vanadous ion. Other metal ions which may be present may also consume 
Figure 2

Spectra of 0.2M Vanadium Formate Solutions

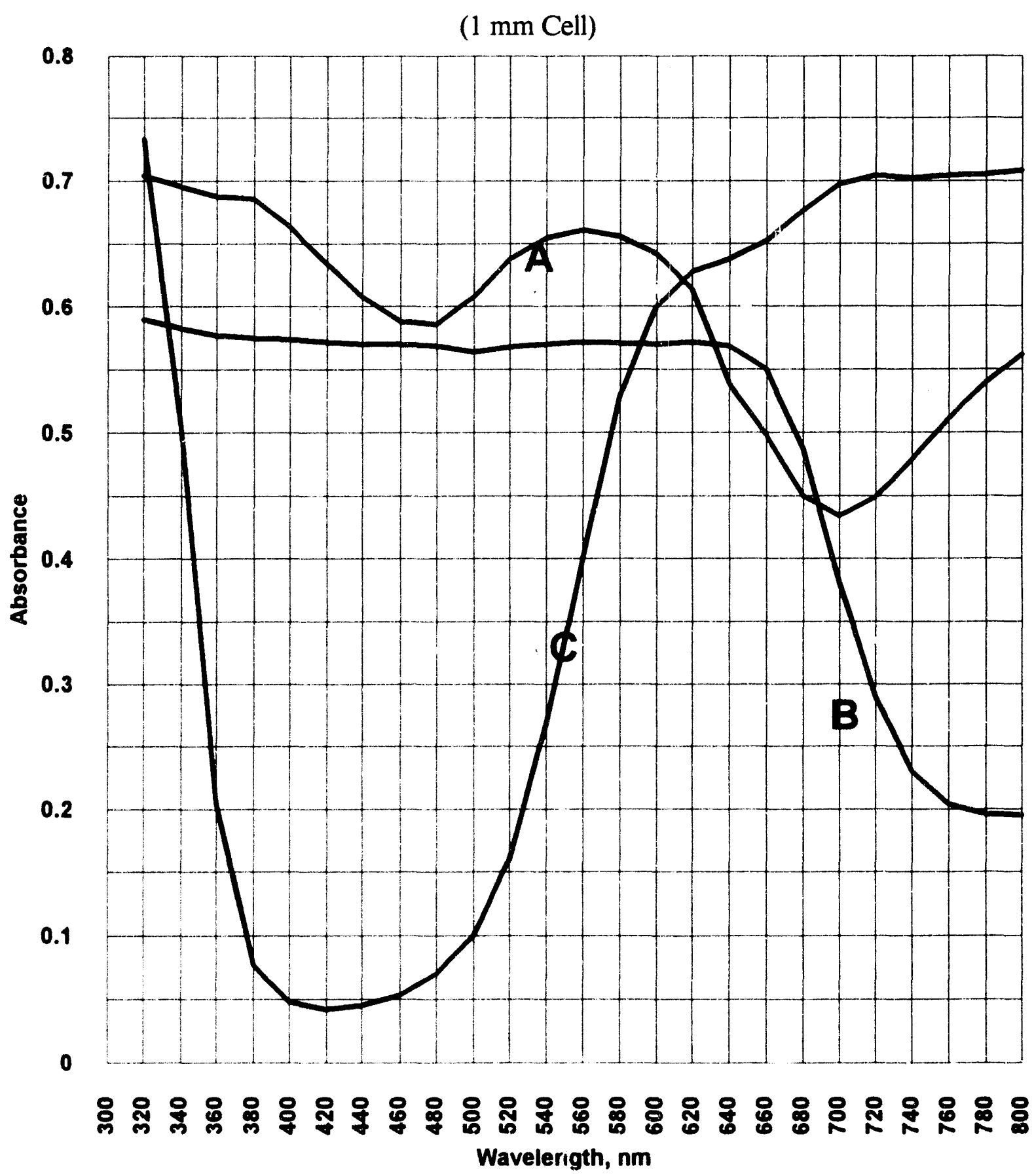

Vanadium Oxidation State: A II B III C IV 
Figure, 3

Spectra of Vanadous Formate/Picolinic Acid Solutions

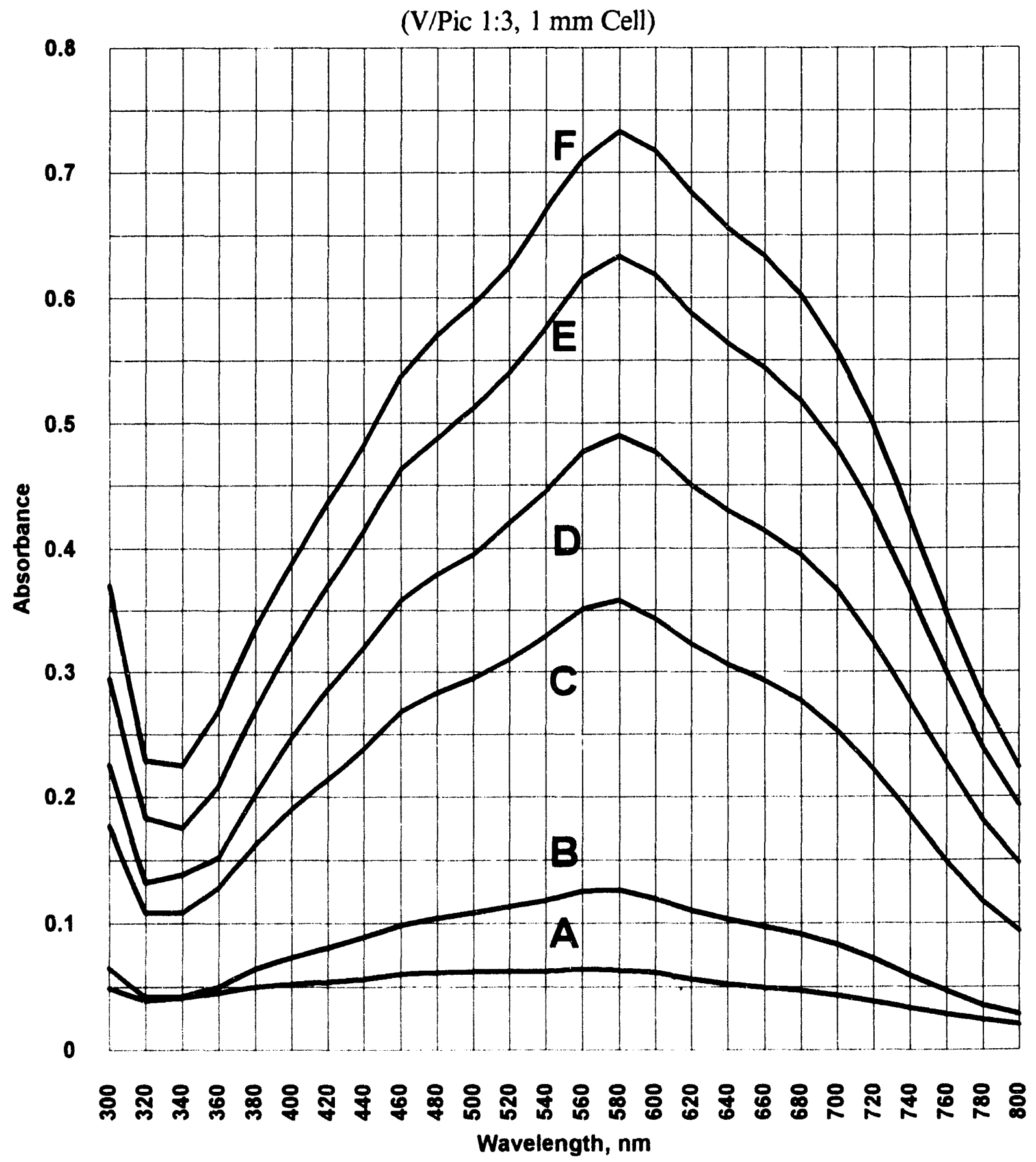

Vanadium Concentration, mM: A 1.11 B 2.22 C 5.55 D 6.66 E 8.88 F 11.1 
Table 1

Absorbance of V(II) Formate/Picolinic Acid

(1:3 V/Pic Ratio)

\begin{tabular}{|c|c|c|c|c|c|c|c|c|}
\hline \multirow{3}{*}{$\begin{array}{c}\mathrm{V}(\mathrm{II}) \\
\text { Concn } \\
\mathrm{mM}\end{array}$} & \multicolumn{6}{|c|}{ Absorbance Values at Indicated Wavelengths } & \multirow{2}{*}{\multicolumn{2}{|c|}{$725 \mathrm{~nm}$}} \\
\hline & \multicolumn{2}{|c|}{$575 \mathrm{~nm}$} & \multicolumn{2}{|c|}{$625 \mathrm{~nm}$} & \multicolumn{2}{|c|}{$675 \mathrm{~nm}$} & & \\
\hline & Value & Avg & Value & Avg & Value & Avg & Value & Avg \\
\hline \multirow[t]{3}{*}{1.11} & 0.101 & & 0.082 & & 0.068 & & 0.046 & \\
\hline & 0.099 & & 0.081 & & 0.066 & & 0.048 & \\
\hline & 0.093 & 0.098 & 0.076 & 0.080 & 0.063 & 0.066 & 0.045 & 0.046 \\
\hline \multirow[t]{3}{*}{2.22} & 0.281 & & 0.239 & & 0.206 & & 0.152 & \\
\hline & 0.283 & & 0.246 & & 0.214 & & 0.164 & \\
\hline & 0.282 & 0.282 & 0.242 & 0.242 & 0.209 & 0.210 & 0.157 & 0.158 \\
\hline \multirow[t]{3}{*}{5.55} & 0.817 & & 0.726 & & 0.642 & & 0.483 & \\
\hline & 0.822 & & 0.741 & & 0.656 & & 0.511 & \\
\hline & 0.821 & 0.820 & 0.732 & 0.733 & 0.650 & 0.649 & 0.502 & 0.499 \\
\hline \multirow[t]{3}{*}{6.66} & 1.058 & & 0.959 & & 0.858 & & 0.658 & \\
\hline & 1.064 & & 0.971 & & 0.874 & & 0.686 & \\
\hline & 1.058 & 1.060 & 0.959 & 0.963 & 0.855 & 0.862 & 0.670 & 0.671 \\
\hline \multirow[t]{3}{*}{8.88} & 1.354 & & 1.246 & & 1.128 & & 0.879 & \\
\hline & 1.353 & & 1.250 & & 1.132 & & 0.894 & \\
\hline & 1.355 & 1.354 & 1.248 & 1.248 & 1.130 & 1.130 & 0.887 & 0.887 \\
\hline \multirow[t]{3}{*}{11.1} & 1.736 & & 1.607 & & 1.461 & & 1.151 & \\
\hline & 1.738 & & 1.618 & & 1.473 & & 1.173 & \\
\hline & 1.737 & 1.737 & 1.609 & 1.611 & 1.463 & 1.466 & 1.154 & 1.159 \\
\hline \multicolumn{2}{|c|}{ Correlation coefficient } & 0.9993 & & 0.9993 & & 0.9993 & & 0.9990 \\
\hline
\end{tabular}


Figure 4

Absorbance of Vanadous Formate/Picolinic Acid Solutions

(V/Pic 1:3, $1 \mathrm{~mm}$ Cell)

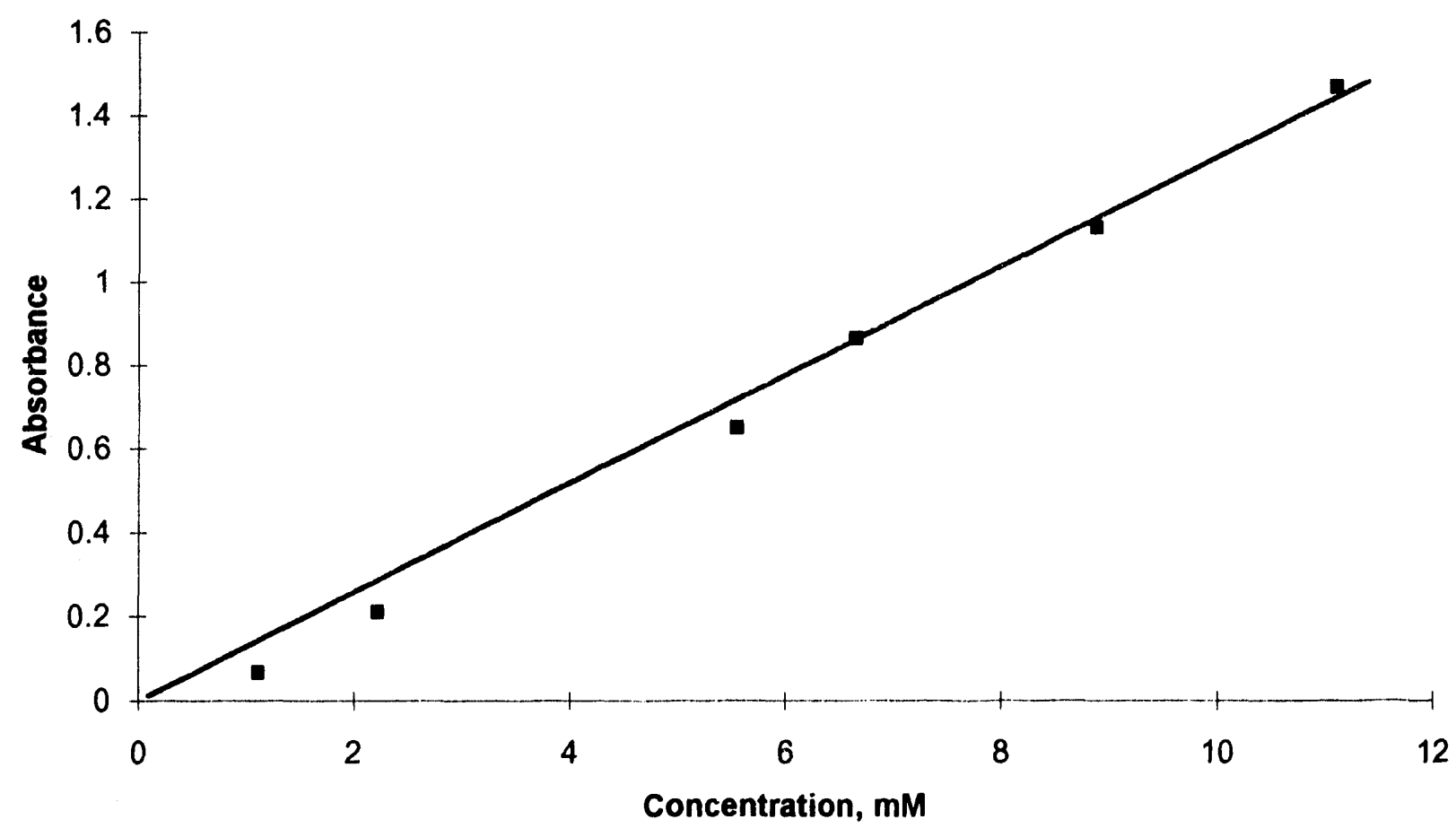


Figure 5

Spectra of Vanadous Formate/Picolinic Acid Solutions

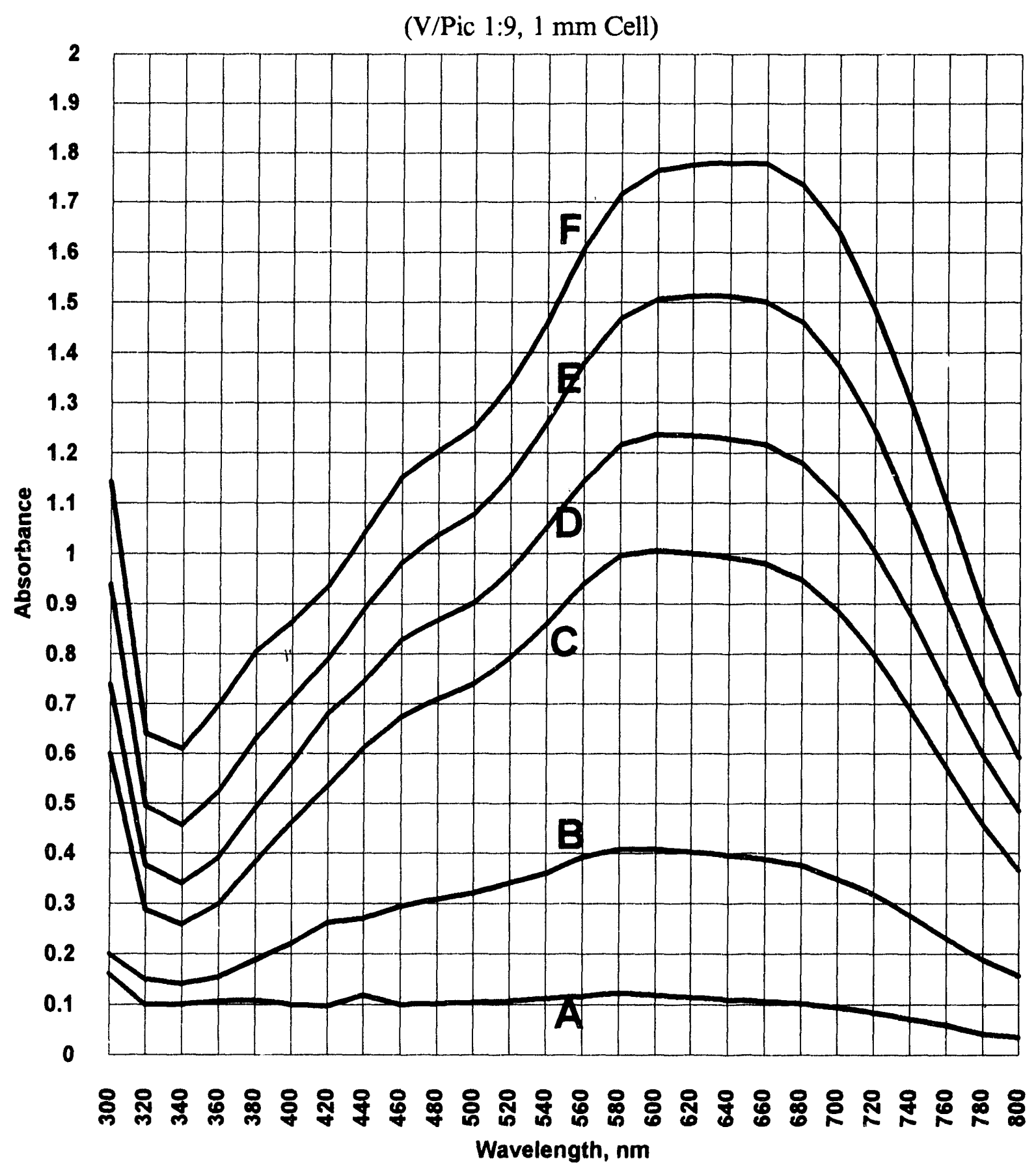

Vanadium Concentration, mM: A 1.11 B 2.22 C 5.55 D 6.66 E 8.88 F 11.1 
Figure 6

Effect of V(II)/Picolinic Acid Ratio on Absorbance

(Averages of All Runs, $565-575 \mathrm{~nm}, 1 \mathrm{~mm}$ Cell)

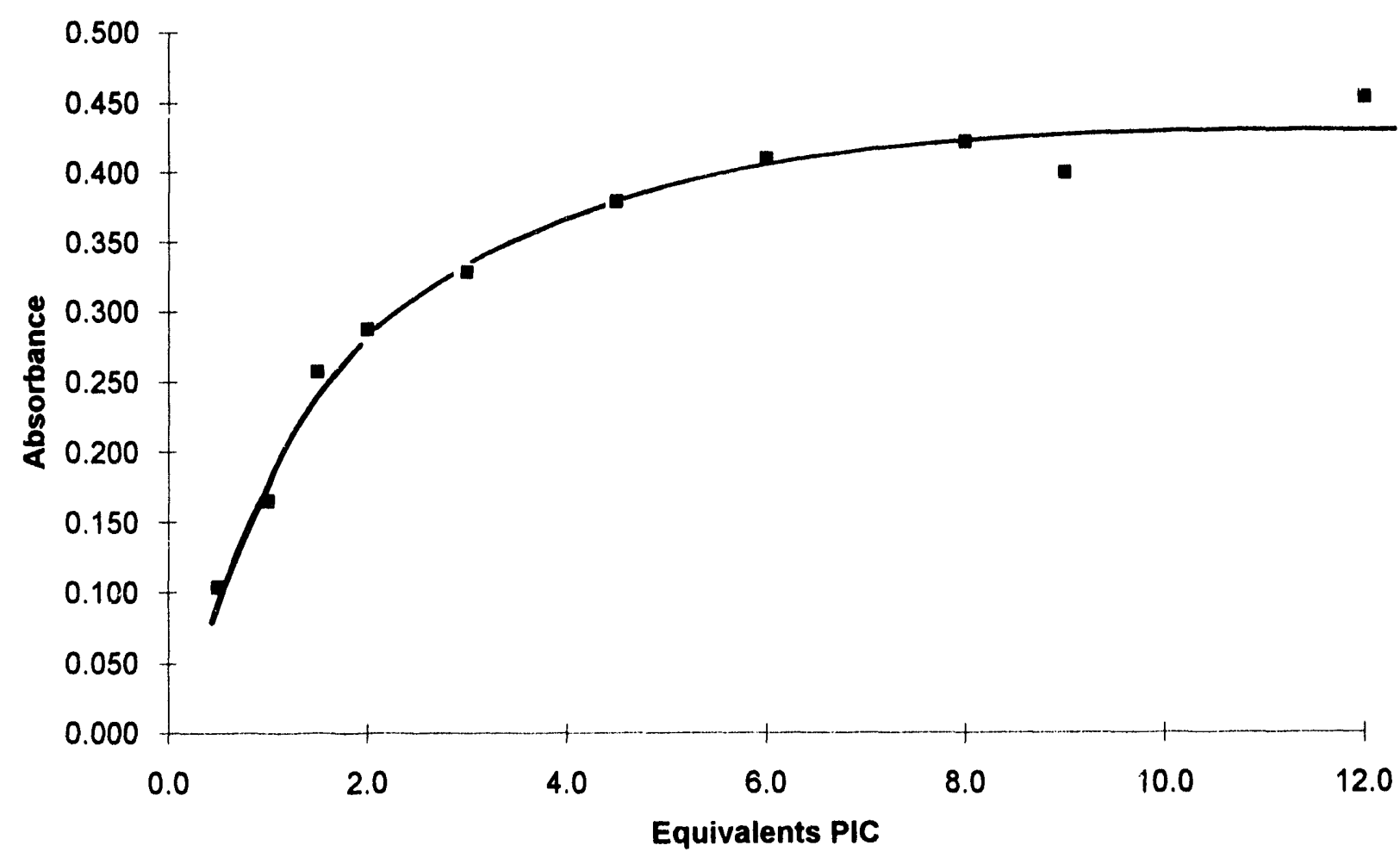


picolinic acid, thereby depriving the vanadous complex to a degree dependent on the relative dissociation constants of the complexes and on the relative concentrations. As a consequence, it may be necessary to have present a large excess of picolinic acid in order to perform the V(II) analysis accurately.

Observation of the solution $\mathrm{pH}$ showed that it decreased as the picolinic acid concentration was increased. (See Table 2 and Figure 7.) The decrease in $\mathrm{pH}$ was accompanied by a shift in the wavelength of maximum absorbance (Figure 8). These effects, which require further investigation, will have to be taken into consideration in designing an on-stream analyzer. It may become necessary to both (1) provide an excess of picolinic acid and (2) control the $\mathrm{pH}$ of the sample solution to a constant value.

The potential for interference by iron and nickel was evaluated by separately examining $0.005 \mathrm{M} \mathrm{Fe}(\mathrm{II}), \mathrm{Fe}(\mathrm{III})$, and $\mathrm{Ni}(\mathrm{II})$ solutions with a $3 / 1$ ratio of picolinic acid present. Their spectra are shown in Figure 9. The maximum concentrations experienced in the LOMI work described in Reference 1 may be calculated to be $0.009 \mathrm{M}$ iron and $0.002 \mathrm{M}$ nickel. The spectra show for wavelengths above $550 \mathrm{~nm}$, the interference will be negligible.

\section{CONCLUSIONS AND RECOMMENDATIONS}

This work shows that it is feasible to follow V(II) concentration in a LOMI decontamination spectrophotometrically. The results show that it will be feasible to develop a continuous monitoring instrument which can be used on-line during LOMI decontaminations.

At concentrations which are typical of LOMI decontaminations, iron and nickel pose no interference to the V(II) analysis, except indirectly, by reducing the concentration of picolinic acid available to form the $\mathrm{V}$ (II) complex. Because the iron and nickel, as well as other metallic ions which might be present, can consume picolinic acid, it may be necessary to add a large excess of picolinic acid to the analytical sample. It may be necessary to insure that the $\mathrm{pH}$ of the analyte is maintained at a constant value in order to avoid affecting the $\mathrm{V}$ (II) complex concentration. 
The reflectance method using a prism cell was not suitable for measurement of vanadium species in the infrared spectral region, although it could be useful for measuring the concentrations of organic compounds which may be present in the aqueous medium. The potential of a suitable prism cell for analysis on the visible spectral region should be further evaluated. 
Table 2

Wavelength Shifts for V(II)/Pic Complex

$\begin{array}{ccccccc}\begin{array}{c}\text { V(II) } \\ \text { Concn } \\ \mathrm{mM}\end{array} & \mathrm{pH} & \mathrm{nm} & \mathrm{pH} & \mathrm{nm} & \mathrm{pH} & \mathrm{nm} \\ & & & & & & \\ 1.11 & 3.37 & 564 & 3.30 & 572 & 3.27 & 580 \\ 2.22 & 3.18 & 570 & 3.07 & 582 & 3.02 & 585 \\ 5.55 & 3.03 & 576 & 2.88 & 590 & 2.82 & 595 \\ 6.66 & 2.96 & 578 & 2.82 & 593 & 2.78 & 600 \\ 8.88 & 2.93 & 579 & 2.77 & 598 & 2.71 & 610 \\ 11.10 & 2.87 & 580 & 2.74 & 600 & 2.68 & 650\end{array}$


Figure 7

pH of Vanadous Formate/Picolinic Acid Solutions

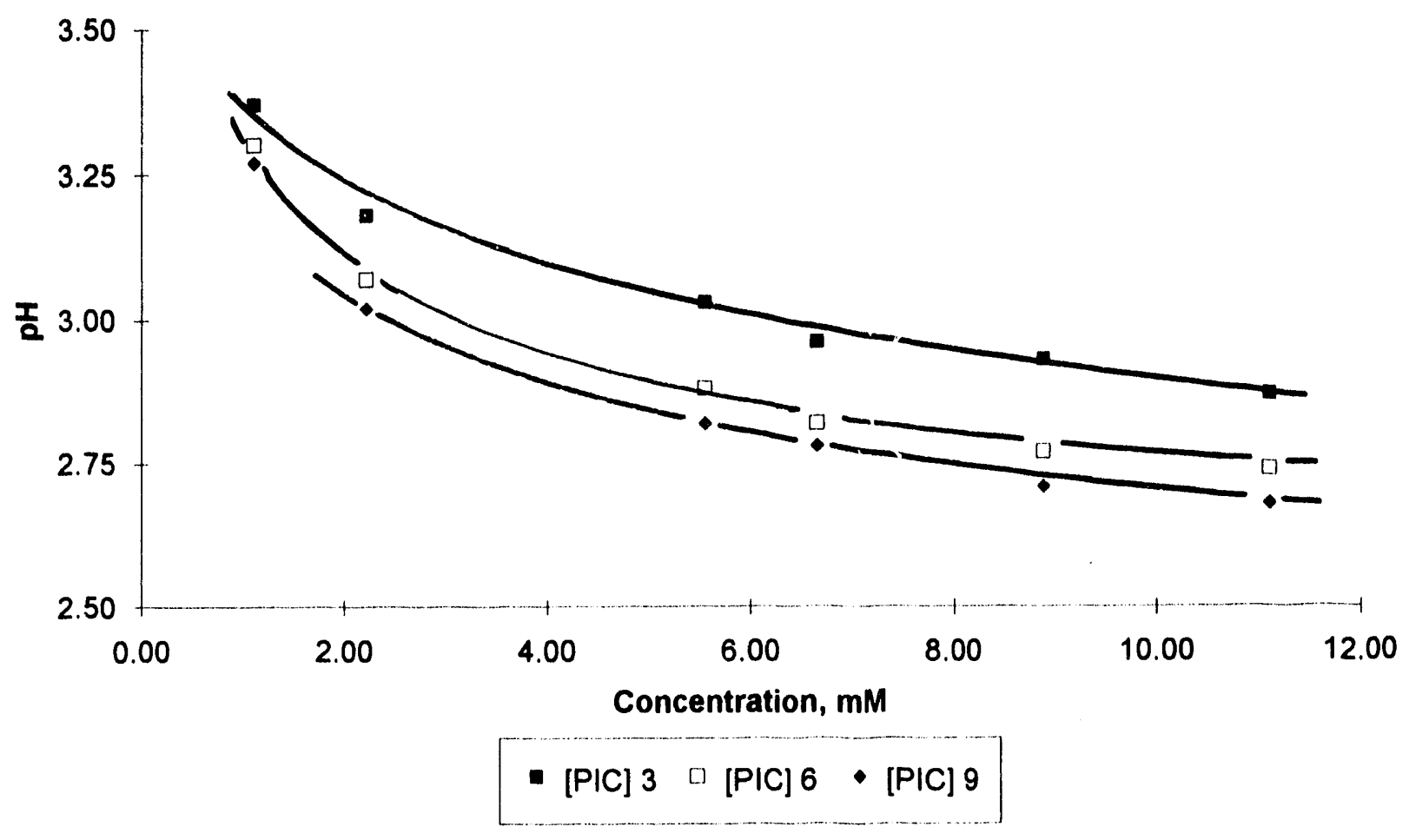




\section{Figure 8}

\section{Wavelength Shifts Accompanying pH Changes}

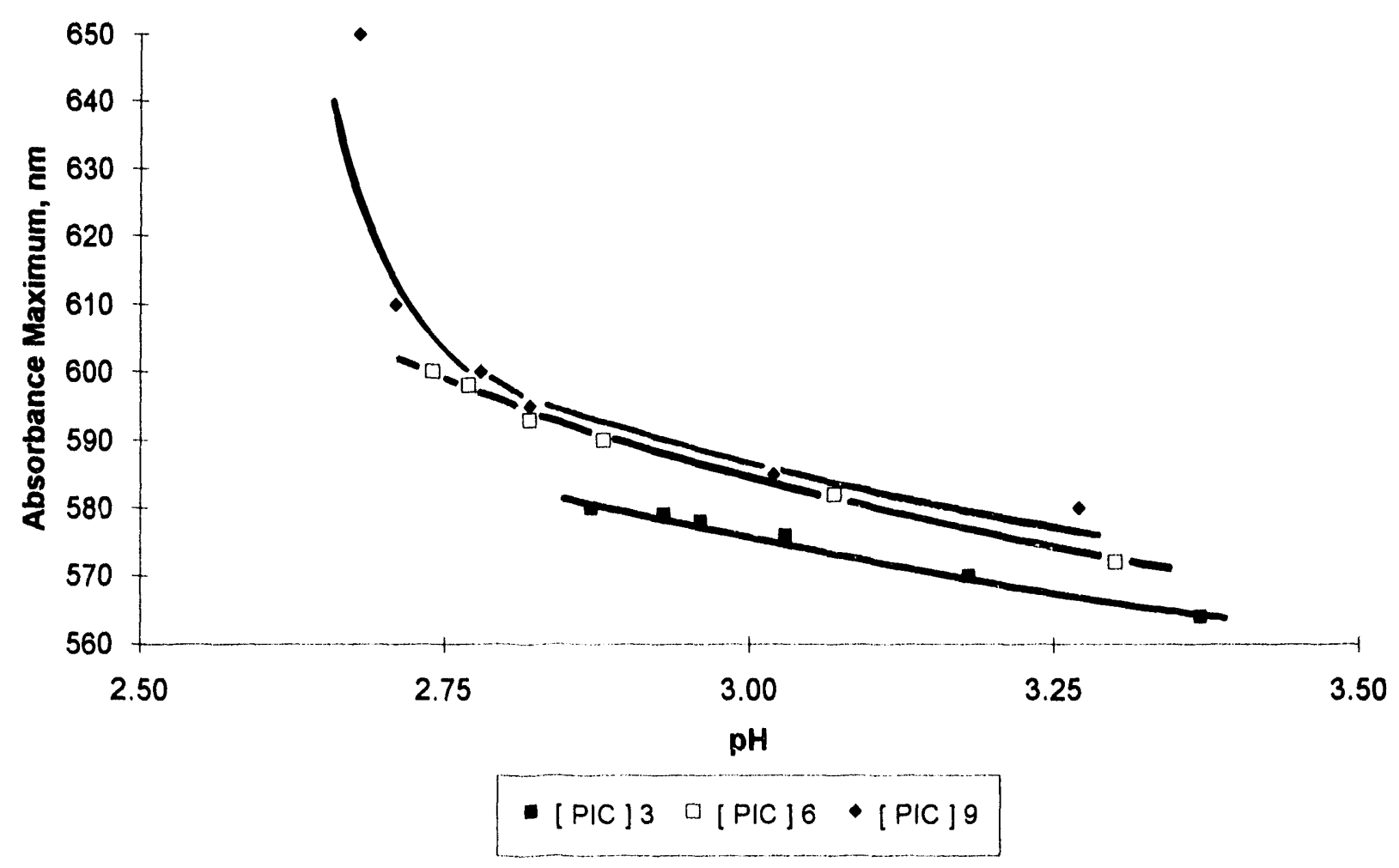


Figure 9

Spectra of Potential Interfering Ions

$$
(0.005 \mathrm{M}, 10 \mathrm{~mm})
$$

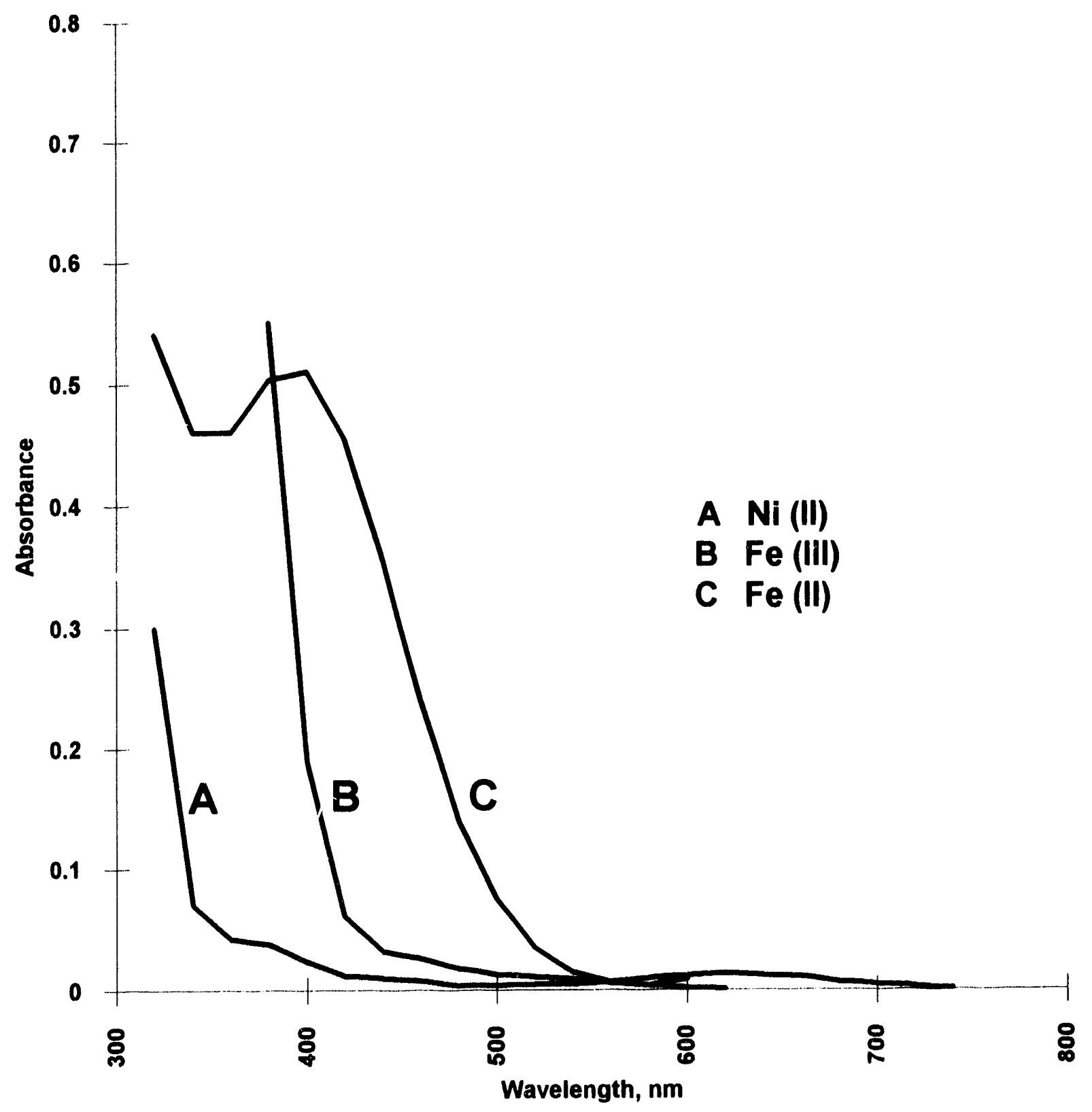




\section{REFERENCES}

1. D. Bradbury, M.E. Pick, M.G. Segal, R.M. Sellers, T. Swan, N.R. Large, and J.Monahan, "Experience of Plant Decontamination with LOMI Reagents", in Water Chemistry of Nuclear Reactor Systems, British Nuclear Energy Society, London, Vol 3, p.203, 1980.

2. M.G. Segal and R.M. Sellers, J. Chem. Soc. Faraday I, p.1149, 1982.

3. R.J.H. Clark, The Chemistry of Titanium and Vanadium, Elsevier Publishing Company, New York, NY, 1968.

4. Chemical Analysis of Vanadous Formate, Method 1-053, Monarch Analytical Laboratories, Inc., P.O. Box 2990, Toledo, OH, 1992.

5. I.M. Kolthoff and R. Belcher, Volumetric Analysis, Interscience Publishers, Inc., New York, NY, Volume 3, 1957.

6. S.C. Furman and C.S. Garner, "Absorption Spectra of Vanadium (III) and Vanadium (IV) Ions in Complexing and Non-complexing Media", $J$. Am. Chem. Soc., 72, p.1785, 1950.

7. T.W. Newton and F.B. Baker, "The Kinetics of the Reaction between Vanadium (II) and Vanadium (IV)", J. Phys. Chem., 68, p.228, 1964.

8. N. Harrick, M. Milosevic, and S. Berets, Appl. Spectrosc., 45, p.944, 1991. 


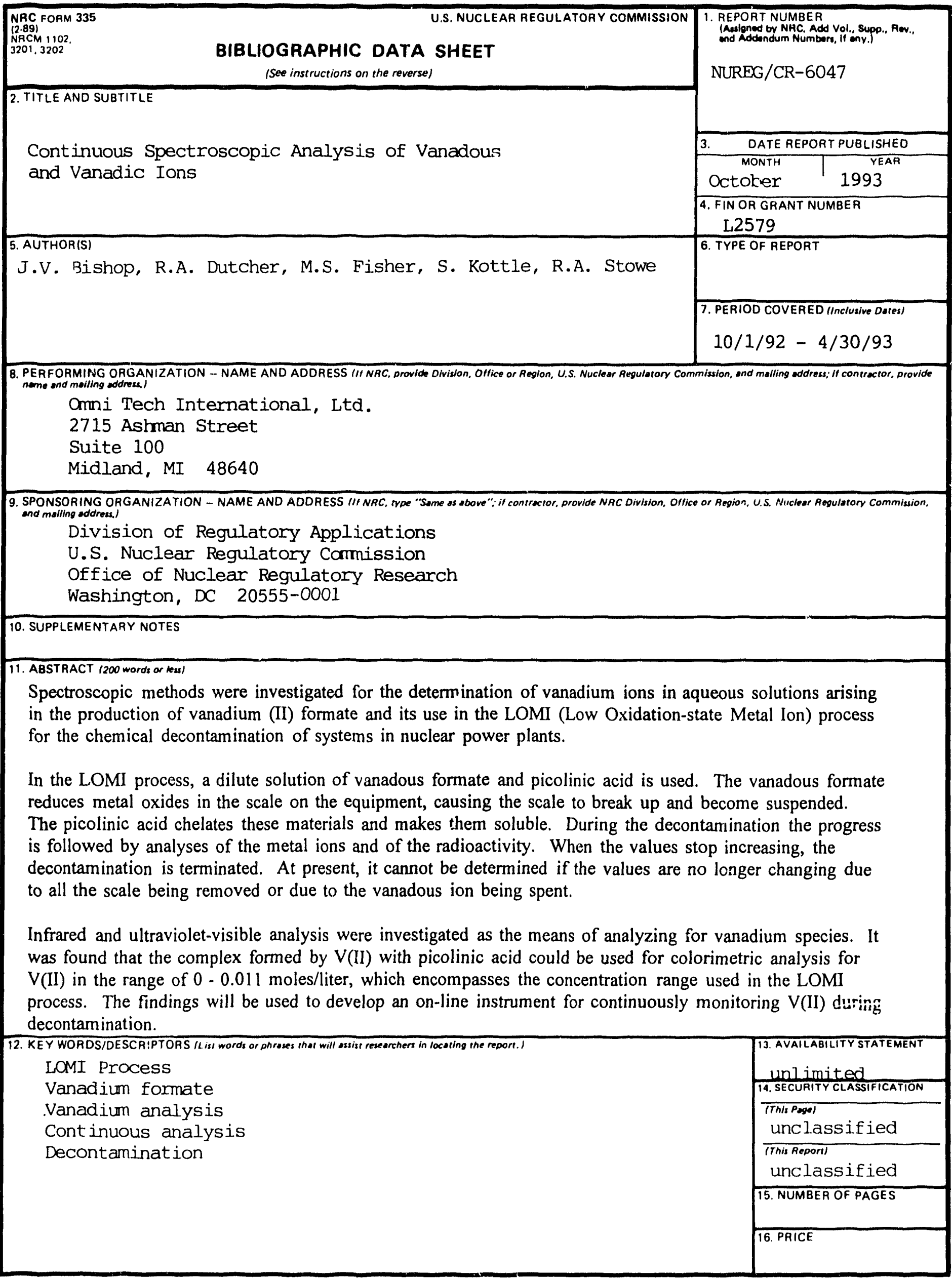



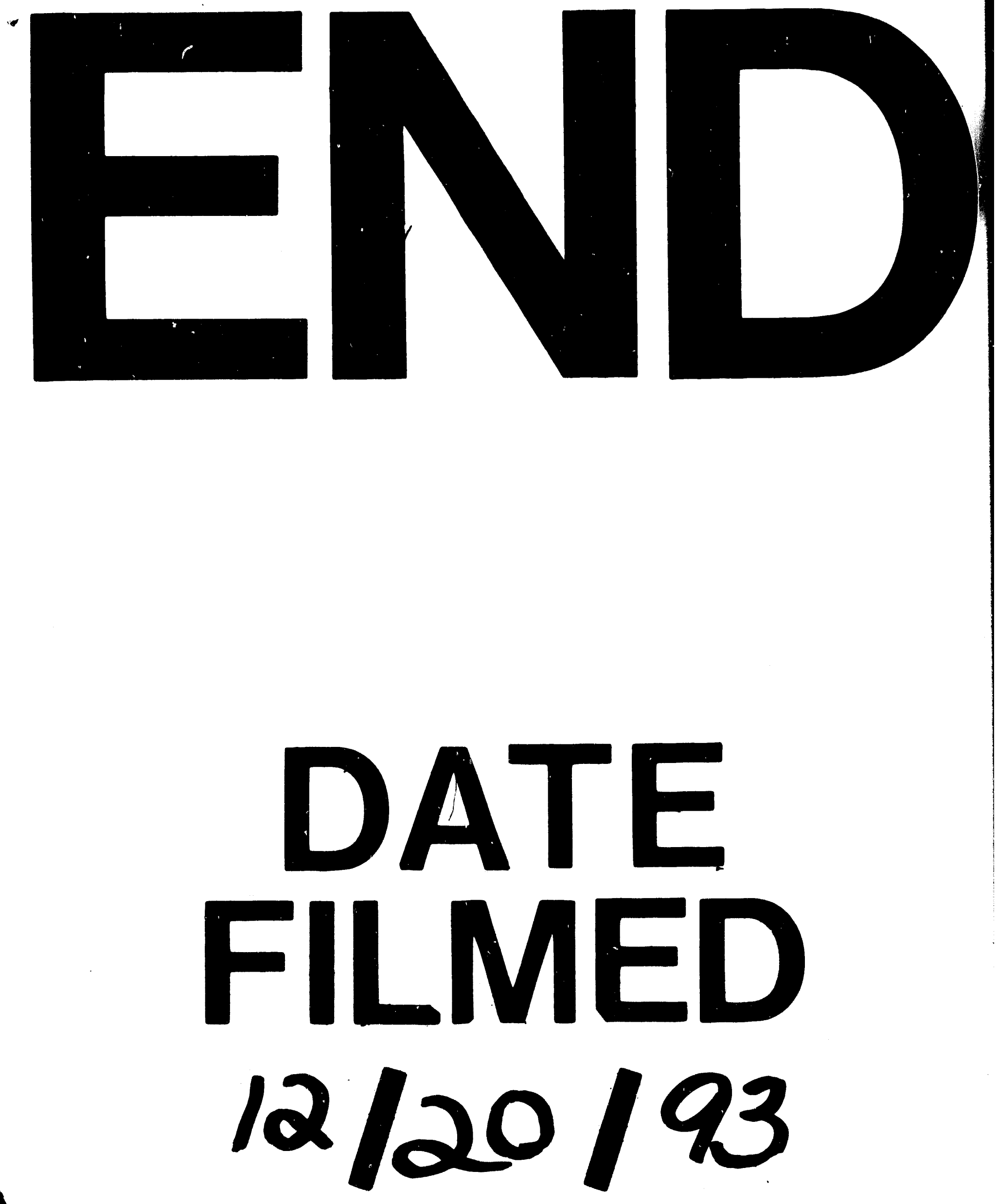

1 
